\title{
Pengaruh Pentagon Fraud Terhadap Fraudulent Financial Statement Dengan Kualitas Laba Sebagai Variabel Moderasi
}

\author{
Abdurrachman ${ }^{1,{ }^{*}}$, Suhartono ${ }^{1}$ \\ ${ }^{1}$ Fakultas Ekonomi \& Bisnis, Universitas Bina Sarana Infromatika, Jln. Kramat Raya No. \\ 98, Kwitang, Senen, Jakarta Pusat 10450. 021-8000063; e-mail: abdurrachman.bdr@bsi.ac.id; \\ suhartono.sht@bsi.ac.id \\ * Korespondensi: e-mail: abdurrachman.bdr@bsi.ac.id
}

\begin{abstract}
Financial statement fraud is a serious and constructive problem for external parties of the company, especially for investors. This study aims to factors that cause false financial statements with variables as moderating variables. The factors used in this study are pentagon fraud theory which consists of variables of pressure, opportunity, rationalization, competence, and arrogance. This study uses the company in the Indonesia Stock Exchange 2016-2017 period as a research sample. Based on the results of purposive sampling obtained 204 data manufacturing companies that meet the sample. Testing the hypothesis in this study was carried out using logistic regression analysis. The results of testing the hypothesis to see the effect on fraudulent financial statements indicate that competence has a significant positive effect, pressure has a negative effect, the opportunity has no significant effect, rationalization has no significant effect, arrogance has no significant effect. In the moderating variable earnings quality cannot weaken the influence of pressure, opportunity, rationalization and arrogance on fraudulent financial statements, but earnings quality can weaken the influence of competence on fraudulent financial statements. Simultaneous testing shows that the overall variable has a significant effect on fraudulent financial statements.
\end{abstract}

Keywords: Fraudulent Financial Statement, Pentagon Fraud

\begin{abstract}
Abstrak
Kecurangan laporan keuangan merupakan masalah yang serius dan menjadi ancaman bagi pihak-pihak eksternal perusahaan, khususnya bagi investor. Beberapa penelitian mengenai faktor faktor yang berpengaruh pada fraudulent financial statement telah dilakukan. Penelitian ini bertujuan menguji kembali faktor-faktor yang mempengaruhi fraudulent financial statement dengan menambahkan kualitas laba sebagai variabel moderasi. Faktor-faktor yang diuji dalam penelitian ini adalah teori pentagon fraud yang terdiri dari variabel pressure, opportunity, rationalization, competence, dan arrogance. Penelitian ini menggunakan perusahaan manafaktur terdaftar di Bursa Efek Indonesia periode 2016-2017 sebagai sampel penelitian. Berdasarkan hasil purposive sampling diperoleh 204 data perusahaan manufaktur yang memenuhi kriteria sampel. Pengujian hipotesis dalam penelitian ini dilakukan dengan menggunakan analisis regresi logistik. Hasil pengujian hipotesis untuk melihat pengaruh terhadap fraudulent financial statement menunjukkan bahwa competence berpengaruh positif signifikan, pressure berpengaruh negatif, opportunity tidak berpengaruh signifikan,
\end{abstract}


rationalization tidak berpengaruh signifikan, arrogance tidak berpengaruh signifikan. Pada variabel moderasi kualitas laba tidak dapat memperlemah pengaruh pressure, opportunity, rationalization dan arrogance terhadap fraudulent financial statement, namun kualitas laba dapat memperlemah pengaruh competence pada fraudulent financial statement. Pengujian secara simultan menunjukkan bahwa variabel secara keseluruhan berpengaruh signifikan terhadap fraudulent financial statement.

Kata kunci: Fraudulent Financial Statement, Pentagon Fraud

\section{Pendahuluan}

\subsection{Latar Belakang}

Tekanan ekonomi global menimbulkan ancaman bagi pelaku usaha dan para pengambil keputusan. Mereka sangat memerlukan laporan keuangan sebagai informasi untuk melihat seberapa mampu perusahaan dapat bertahan ditengah tekanan global. Gambaran dari informasi tersebut menjadi acuan untuk menetapkan strategi selanjutnya. Melihat dari pentingnya laporan keuangan sebagai alat pengambil keputusan, maka sangat perlu diperhatikan bahwa laporan keuangan harus memiliki kualitas tinggi dan bersih dari adanya unsur dan indikasi fraud, Sebab kecurangan laporan keuangan merupakan masalah yang serius dan menjadi ancaman bagi pihak-pihak eksternal perusahaan, khususnya bagi investor. $\mathrm{Hal}$ itu dikarenakan adanya tindakan ilegal yang secara sengaja dilakukan, seperti mengungkapkan informasi keuangan yang tidak sesuai dengan keadaan yang sebenarnya terjadi (Aprilia, O Cicilia, 2015)

Menurut (Aprilia, 2017), "Fraud Model sudah berkembang dengan pesat dalam beberapa tahun terakhir ini, pertama kali fraud model ditemukan oleh Donald R. Cressey yang kemudian dikenal sebagai fraud triangle. Fraud triangle menggambarkan faktor-faktor yang menyebabkan terjadinya kecurangan. Fraud triangle kemudian berkembang menjadi fraud diamond yang ditemukan oleh (Wolfe \& Hermanson, 2004). Perkembangan model fraud terbaru ditemukan oleh Jonathan Marks dalam (Triyanto, 2019) yang disebut sebagai The Crowe's Fraud Pentagon".

The Crowe's Fraud Pentagon menambahkan elemen arogansi (arrogance) yang juga turut berpengaruh terhadap terjadinya fraud, sehingga The Crowe's Fraud Pentagon terdiri dari lima elemen indikator yaitu tekanan (pressure), kesempatan (opportunity), rasionalisasi (rationalization), kompetensi (competence), dan arogansi (arrogance).

Kasus nyata mengenai kecurangan laporan keuangan di Indonesia, diantaranya terjadi pada PT. Inovisi Intracom Tbk (INVS), di mana sejak awal periode 2015 perdagangan saham Inovisi telah disuspensi oleh Bursa Efek Indonesia (BEI). Seperti yang dilansir dalam detik finance tertulis bahwa setelah mensuspensi saham INVS, Otoritas bursa pun melakukan penelaahan terhadap laporan keuangan perusahaan kuartal III-2014. Dari situ diketahui ada delapan poin dalam laporan keuangan Inovisi yang mencurigakan (Aprilia, O Cicilia, 2015)

Tujuan peneliti ini berdasarkan latar belakang permasalahan yang ada adalah ingin mengetahui seberapa efektif pengaruh Pentagon fraud dalam mendeteksi kecurangan laporan keuangan (fraudulent financial statement) yang dilakukan perusahaan. Yang membedakan 
penelitian ini dengan penelitian sebelumnya yaitu dengan menggunakan kualitas laba sebagai variabel moderasi.

\section{a. Teori Agensi}

Jensen dan Meckling dalam (Aprilia, O Cicilia, 2015) menggambarkan adanya hubungan kontrak antara agen (manajemen) dengan pemilik (principal). Agen diberi wewenang oleh pemilik untuk melakukan operasional perusahaan, sehingga agen lebih banyak mempunyai informasi dibandingkan pemilik. Ketimpangan informasi ini biasa disebut sebagai asymetric information. Baik pemilik maupun agen diasumsikan mempunyai rasionalisasi ekonomi dan semata-mata mementingkan kepentingannya sendiri. Agen mungkin akan takut mengungkapkan informasi yang tidak diharapkan oleh pemilik, sehingga terdapat kecenderungan untuk memanipulasi laporan keuangan tersebut.

b. Teori Akuntansi Positif

Teori akuntansi positif dikemukakan oleh Watts dan Zimmerman. Teori akuntansi bertujuan untuk menguraikan dan menjelaskan bagaimana proses akuntansi dari awal hingga masa sekarang dan bagaimana informasi akuntansi disajikan agar dapat dikomunikasikan kepada pihak lain didalam perusahaan.

Hipotesis dari penelitian yang akan dilakukan berdasarkan permasalahan dan tujuan yang ada dapat diuraikan sebagai berikut:

H1: Pressure berpengaruh positif terhadap Fraudulent Financial Statement

H2: Opportunity berpengaruh positif terhadap Fraudulent Financial Statement

H3: Rationalization berpengaruh positif terhadap Fraudulent Financial Statement

H4: Competence berpengaruh positif terhadap Fraudulent Financial Statemet

H5: Arrogance berpengaruh positif terhadap Fraudulent Financial Statement

H6: Kualitas Laba memperlemah pengaruh Pressure terhadap Fraudulent Financial Statement

H7: Kualitas Laba memperlemah pengaruh Opportunity terhadap Fraudulent Financial Statement

H8: Kualitas Laba memperlemah pengaruh Rationalization terhadap Fraudulent Financial Statement

H9: Kualitas Laba memperlemah pengaruh Competence terhadap Fraudulent Financial Statemen

H10: Kualitas Laba memperlemah pengaruh Arrogance terhadap Fraudulent Financial Statement

\section{Metode Penelitian}

Sampel ditentukan dengan metode purposive sampling. Purposive sampling merupakan metode pengumpulan data dengan pertimbangan kriteria tertentu. Kriteria yang ditetapkan dalam penentuan sampel dalam penelitian ini adalah sebagai berikut:

Copyright @ 2020 Jurnal JKI 20 (3): 269 - 280 (September 2020) 
1. Perusahaan manufakur yang sudah go public atau terdaftar di Bursa Efek Indonesia (BEI) selama periode 2016-2017.

2. Perusahaan mempublikasikan laporan keuangan tahunan dalam website perusahaan atau website BEI selama periode 2016-2017.

3. Data mengenai data-data yang berkaitan dengan variabel penelitian tersedia dengan lengkap (data secara keseluruhan tersedia pada publikasi selama periode 2016-2017).

4. Perusahaan-yang tidak delisting dari BEI selama periode pengamatan (2016-2017).

Teknik analisis yang digunakan adalah regresi logistik. Persamaan regresi yang digunakan dalam pengujian hipotesis adalah sebagai berikut:

M-Scoreit $=$ BO + B1ACHANGEit + B2BDOUTit + B3CIAit + B4CIDit + B5CEOPICit + B6DACC

+ B7ACHANGE*DACC + B8DOUT*DACC + B9CIA*DACC + B10CID*DACC+ B11CEOPIC*DACC $+\varepsilon i t$

Keterangan:

BO = Koefisien regresi konstanta

B1-10= Koefisien regresi masing-masing proksi

M-Scoreit $=1$ jika manipulator dan 0 jika non manipulator

ACHANGE = Rasio perubahan total aset tahun 2016-2017

BDOUT = rasio dewan komisaris independen

CIA = Pergantian Auditor Independen

$\mathrm{CID}=$ Pergantian Direksi

CEOPIC = Jumlah foto CEO yang terdapat dalam sebuah laporan tahunan

DACC = Kualitas Laba dengan menggunakan discretionary accrual

$\varepsilon=$ error

Data yang dikumpulkan dalam penelitian ini diolah dan kemudian dianalisis dengan alat statistik yang terdiri dari : Statistik Deskriptif, Metode Hosmer and Lemeshow Test (goodness of-fit-test), Uji Penilaian Keseluruhan Model (Overall Model Fit), Koefisien Determinasi (Nagelkerke R Square), Uji Multikolinieritas dan Pengujian Hipotesis.

\section{Hasil dan Pembahasan}

\subsection{Analisis Hasil Penelitian}

\section{a. Analisis Statistik Deskriptif}

Berdasarkan hasil statistik deskriptif dengan metode purposive sampling, diperoleh 204 data observasi yang digunakan untuk analisis statistik yang berasal dari perkalian antara periode penelitian ( 2 tahun; dari tahun 2016 sampai 2017) dengan jumlah perusahaan sampel (154 perusahaan).

\section{b. Pengujian Kelayakan Model Regresi (Hosmer and Lemeshow's Goodness of Fit Test)}

Hasil uji Hosmer and Lemeshow Goodness of Fit Test ditunjukkan bahwa besarnya nilai Chi-square dari Hosmer and Lemeshow Goodness of Fit adalah sebesar 8,136 dengan 
probabilitas signifikansi 0,420 dimana $0,420>0,05$. Hal ini berarti model regresi yang dipergunakan dalam penelitian ini layak dipakai untuk analisis selanjutnya, karena terdapat kecocokan antara model regresi dengan data aslinya.

\section{c. Menilai Keseluruhan Model (Overall Model Fit)}

Dari model tersebut ternyata overall model fit pada $-2 \mathrm{LL}$ Block Number $=0$ menunjukkan adanya penurunan pada -2LL Block Number $=1$ yaitu sebesar 271,403 - 243,042 = 28,361. Penurunan likelihood ini menunjukkan model regresi yang lebih baik atau dengan kata lain model yang dihipotesiskan fit dengan data.

\section{d. Koefisien Determinasi (Nagelkerke R Square)}

Hasil ini menunjukkan bahwa kemampuan kombinasi ketiga variabel independen, yaitu pressure, opportunity, rationalization, competence, dan arrogance dalam menjelaskan variasi variabel dependen (terikat), fraudulent financial statement, relatif rendah yaitu sebesar $17,6 \%$ sedangkan sisanya sebesar $82,4 \%$ dijelaskan oleh faktor-faktor lain yang tidak diikutsertakan dalam model penelitian.

\section{e. Pengujian Ketepatan Prediksi}

Hasil pengujian menunjukkan bahwa dari 126 data yang dianalisis terhadap perusahaan yang non manipulator ternyata diprediksi terdapat 14 data pengamatan perusahaan yang manipulator dan terdapat 112 data pengamatan perusahaanyang non manipulator atau memiliki persentase ketepatan prediksi sebesar $88,9 \%$, sedangkan dari 78 data yang dianalisis terhadap perusahaan yang manipulator ternyata diprediksi terdapat 23 data pengamatan yang non manipulator dan 55 data pengamatan yang manipulator atau memiliki persentase ketepatan prediksi sebesar $295,0 \%$.

Dapat dilihat bahwa Overall Percentage yang dihasilkan adalah sebesar 66,2\%. Dari hasil tersebut dapat diambil kesimpulan bahwa persamaan regresi logistik yang telah terbentuk bisa membuat klasifikasi dalam penaksiran nilai Y (fraudulent financial statement), yaitu sebesar $66,2 \%$ artinya model regresi logistik cukup baik dalam melakukan prediksi.

\section{f. Pengujian Multikolinearitas}

Hasil pengujian menunjukkan ada nilai koefisien korelasi antarvariabel yang lebih besar dari 0,8. Dengan demikian dapat disimpulkan terdapat indikasi multikolinearitas antarvariabel bebas tersebut. Adanya indikasi multikolinieritas tersebut tidak menjadi masalah karena hal ini terjadi disebabkan terdapat hubungan variabel independen dengan variabel moderasi.

\section{g. Pengujian Hipotesis Secara Simultan}

Pengujian hipotesis secara simultan menunjukkan hasil Chi-Square sebesar 28,361 dan degree of freedom sebesar 11 dengan probabilitas signifikansi sebesar 0,003. Karena signifikansi lebih kecil dari $\alpha=0.05$ maka dapat disimpulkan bahwa secara simultan pressure, opportunity, competence, dan arrogance berpengaruh terhadap fraudulent financial statement.

Copyright @ 2020 Jurnal JKI 20 (3): 269 - 280 (September 2020) 


\section{h. Pengujian Koefisien Regresi dan Hipotesis}

Tabel 1. Hasil Pengujian Koefisien Regresi

Variables in the Equation

\begin{tabular}{cccccccc}
\hline & $\begin{array}{c}\text { Arah } \\
\text { Hipotesis }\end{array}$ & B & S.E. & Wald & $\begin{array}{c}\text { Sig. One } \\
\text { Tail }\end{array}$ & Kesimpulan \\
\hline Step $1^{\mathrm{a}}$ & ACHANGE & + & -7.70 & 3.49 & 4.86 & 0.01 & Ditolak \\
\hline BDOUT & + & -3.56 & 4.59 & 0.60 & 0.22 & Ditolak \\
\hline CIA & + & -2.03 & 1.44 & 1.99 & 0.08 & Ditolak \\
\hline CID & + & 1.46 & 0.88 & 2.75 & 0.05 & Diterima \\
\hline CEOPIC & + & -0.29 & 0.33 & 0.75 & 0.19 & Ditolak \\
\hline DACC & + & -0.58 & 3.10 & 0.04 & 0.43 & Ditolak \\
\hline ACHANGE_DACC & - & 18.11 & 6.71 & 7.29 & 0.00 & Ditolak \\
\hline BDOUT_DACC & - & 1.41 & 7.84 & 0.03 & 0.43 & Ditolak \\
\hline CIA_DACC & - & 3.66 & 2.40 & 2.32 & 0.06 & Ditolak \\
\hline CID_DACC & - & -3.29 & 1.57 & 4.37 & 0.02 & Diterima \\
\hline CEOPIC_DACC & - & 0.67 & 0.55 & 1.51 & 0.11 & Ditolak \\
\hline Constant & & 0.82 & 1.86 & 0.19 & 0.33 & \\
\hline
\end{tabular}

a. Variable(s) entered on step 1: ACHANGE, BDOUT, CIA, CID, CEOPIC, DACC, ACHANGE_DACC, BDOUT_DACC, CIA_DACC, CID_DACC, CEOPIC_DACC.

Sumber: Hasil Penelitian (2020)

Pengujian hipotesis dilakukan dengan cara membandingkan antara tingkat signifikansi (sig) dengan tingkat kesalahan $(\alpha)=5 \%$. Berdasarkan Tabel 1 dapat diinterpretasikan hasil sebagai berikut ini:

1. Pengujian hipotesis pertama $(\mathrm{H} 1)$

Hipotesis pertama menyatakan bahwa pressure berpengaruh positif pada fraudulent financial statement. Hasil pengujian menunjukkan variabel pressure yang diukur dengan financial stability (ACHANGE) memiliki koefisien regresi negatif sebesar $-7,70$ dengan tingkat signifikansi 0,014 yang lebih kecil dari $\alpha(5 \%)$.

2. Pengujian hipotesis kedua $(\mathrm{H} 2)$

Hipotesis kedua menyatakan bahwa opportunity berpengaruh positif pada fraudulent financial statement. Hasil pengujian menunjukkan variabel opportunity yang diukur dengan ineffective monitoring (BDOUT) memiliki koefisien regresi negatif sebesar $-3,56$ dengan tingkat signifikansi 0,219 yang lebih besar dari $\alpha(5 \%)$.

3. Pengujian hipotesis ketiga $(\mathrm{H} 3)$

Hipotesis ketiga menyatakan bahwa rationalization berpengaruh positif pada fraudulent financial statement. Hasil pengujian menunjukkan variabel rationalization yang diukur dengan Change In Auditor (CIA) memiliki koefisien regresi negatif sebesar -2,03 dengan tingkat signifikansi 0,080 yang lebih besar dari $\alpha(5 \%)$.

4. Pengujian hipotesis keempat $(\mathrm{H} 4)$

Hipotesis keempat menyatakan bahwa competence berpengaruh positif pada fraudulent financial statement. Hasil pengujian menunjukkan variabel competence yang diukur dengan 
Change In Director (CID) memiliki koefisien regresi positif sebesar 1,46 dengan tingkat signifikansi 0,049 yang lebih kecil dari $\alpha(5 \%)$.

5. Pengujian hipotesis kelima (H5)

Hipotesis kelima menyatakan bahwa arrogance berpengaruh positif pada fraudulent financial statement. Hasil pengujian menunjukkan variabel arrogance yang diukur dengan Frequent Number Of CEO's Picture (CEOPIC) memiliki koefisien regresi negatif sebesar -0,58 dengan tingkat signifikansi 0,75 yang lebih besar dari $\alpha(5 \%)$.

6. Pengujian hipotesis keenam (H6) Hipotesis keenam menyatakan bahwa kualitas laba memperlemah pengaruh pressure terhadap fraudulent financial statement. Hasil pengujian menunjukkan variabel kualitas laba (DACC) dengan memiliki koefisien regresi positif sebesar 18,11 dengan tingkat signifikansi 0,004 yang lebih kecil dari $\alpha(5 \%)$.

7. Pengujian hipotesis ketujuh $(\mathrm{H} 7)$

Hipotesis ketujuh menyatakan bahwa kualitas laba memperlemah pengaruh opportunity terhadap fraudulent financial statement. Hasil pengujian menunjukkan variabel kualitas laba (DACC) dengan memiliki koefisien regresi positif sebesar 1,41 dengan tingkat signifikansi 0,429 yang lebih besar dari $\alpha(5 \%)$.

8. Pengujian hipotesis kedelapan (H8)

Hipotesis kedelapan menyatakan bahwa kualitas laba memperlemah pengaruh rationalization terhadap fraudulent financial statement. Hasil pengujian menunjukkan variabel kualitas laba (DACC) dengan memiliki koefisien regresi positif sebesar 3,66 dengan tingkat signifikansi 0,064 yang lebih besar dari $\alpha(5 \%)$.

9. Pengujian hipotesis kesembilan (H9)

Hipotesis kesembilan menyatakan bahwa kualitas laba memperlemah pengaruh competence terhadap fraudulent financial statement. Hasil pengujian menunjukkan variabel kualitas laba (DACC) dengan memiliki koefisien regresi negatif sebesar -3,29 dengan tingkat signifikansi 0,019 yang lebih kecil dari $\alpha(5 \%)$.

10.Pengujian hipotesis kesepuluh ( $\mathrm{H} 10)$

Hipotesis kesepuluh menyatakan bahwa kualitas laba memperlemah pengaruh arrogance terhadap fraudulent financial statement. Hasil pengujian menunjukkan variabel kualitas laba (DACC) dengan memiliki koefisien regresi positif sebesar 0,67 dengan tingkat signifikansi 0,110 yang lebih besar dari $\alpha(5 \%)$.

\subsection{Pembahasan Hasil Penelitian}

\section{a. Pressure berpengaruh positif terhadap Fraudulent Financial Statement}

Hasil penelitian ini menolak hipotesis pertama. Financial stability yang digunakan untuk melihat pengaruh tekanan terhadap kecurangan laporan keuangan. Stabilitas keuangan yang berubah dapat dilihat dari rasio perubahan total asset. Penelitian ini menunjukkan perubahan

Copyright @ 2020 Jurnal JKI 20 (3): 269 - 280 (September 2020) 
total asset tidak menjamin adanya tindak kecurangan laporan keuangan bisa jadi perubahan total aset terjadi disebabkan oleh penjualan atau pembelian aset tetap dan atau adanya suntikan dana tunai dari investor. Namun dapat terindikasi fraud jika dalam rangka mencapai target finansial, perusahaan akan didorong untuk menggunakan metode akuntansi yang akan menaikkan atau menurunkan nilai dari asset perusahaan seperti mekanisme fair value dan kapitalisasi asset (Albrecht \& Albrecht, C., \& Albrecht, 2008)

\section{b. Opportunity berpengaruh positif terhadap Fraudulent Financial Statement}

Hasil penelitian ini menolak hipotesis kedua. Ineffective monitoring yang digunakan untuk melihat pengaruh peluang terhadap kecurangan laporan keuangan dalam penilitian ini menunjukkan bahwa jumlah komisaris independen yang banyak tidak efektif mencegah tindak kecurangan laporan keuangan terjadi dikarenakan banyaknya komisaris dapat menimbulkan conflict of interest. Menurut (Sihombing, Samuel, \& Rahardjo, 2014), secara umum keberadaan dewan komisaris independen akan memberikan sedikit jaminan bahwa pengawasan perusahaan akan semakin independen dan objektif serta jauh dari intervensi pihakpihak tertentu. Semakin banyak komisaris independen diharapkan akan semakin meningkatkan kinerja perusahaan. Namun akan berbeda apabila terdapat intervensi kepada dewan komisaris independen yang mengakibatkan tidak objektifnya suatu pengawasan yang dilakukan oleh dewan komisaris independen tersebut sehingga jumlah atau banyaknya dewan komisaris independen dalam suatu perusahaan bukan merupakan suatu faktor yang signifikan dalam peningkatan pengawasan operasional perusahaan".

\section{c. Rationalization berpengaruh positif terhadap Fraudulent Financial Statement}

Hasil penelitian ini menolak hipotesis ketiga. Change in auditor yang digunakan untuk melihat pengaruh rasionalisasi terhadap kecurangan laporan keuangan, dalam penilitian ini menunjukkan bahwa pergantian auditor yang terjadi bisa disebabkan oleh motivasi yang positif dari dewan komisaris independen dan komite audit dengan adanya ketidakpuasan terhadap kinerja auditor yang buruk dan hasil temuan, sehingga dewan komisaris dan komite audit melakukan pergantian auditor. Namun jika pergantian auditor disebabkan oleh motivasi yang negatif karena auditor tidak dapat di intevensi atau dipengaruhi sesuai dengan keinginan maka ini dapat terindikasi fraud.

\section{d. Competence berpengaruh positif terhadap Fraudulent Financial Statement}

Hasil penelitian menerima hipotesis keempat. Change in director yang digunakan untuk melihat pengaruh kompetensi terhadap kecurangan laporan keuangan dalam penilitian ini menunjukkan bahwa pergantian direksi yang kompeten untuk menutupi kecurangan yang dilakukan oleh direksi sebelumnya, karena hanya orang yang kompeten dan tidak memiliki integritas yang baik dapat melakukan kecurangan tanpa mudah untuk diketahui dan ditelusuri. Hasil penelitian ini sesuai dengan pernyataan (Wolfe \& Hermanson, 2004) bahwa "penipuan atau kecurangan tidak mungkin dapat terjadi tanpa orang yang memiliki kemampuan yang tepat untuk melaksanakan penipuan atau kecurangan tersebut. Kemampuan yang dimaksud adalah 
sifat individu melakukan penipuan, yang mendorong mereka untuk mencari kesempatan dan memanfaatkannya".

\section{e. Arrogance berpengaruh positif terhadap Fraudulent Financial Statement}

Hasil penelitian ini menolak hipotesis kelima. Frequent number of CEO's picture yang digunakan untuk melihat pengaruh arogansi terhadap kecurangan laporan keuangan dalam penilitian ini menunjukkan bahwa banyaknya foto CEO yang terpampang dilaporan keuangan tidak menunjukan tindak kecurangan laporan keuangan terjadi, dikarenakan tujuan adanya foto CEO laporan tahunan bisa untuk mengenalkan profile dan prestasi dari CEO dalam perusahaan.

\section{f. Kualitas Laba memperlemah pengaruh Pressure terhadap Fraudulent Financial Statement}

Hasil penelitian ini menolak hipotesis keenam. Penelitian ini menunjukkan bahwa kualitas laba tidak dapat memperlemah tekanan terhadap kecurangan laporan keuangan, dikarenakan bisa jadi tekanan yang di lihat dari perubahan total aset mencerminkan laba yang sebenarnya bukan karena adanya manajemen laba. Contohnya perusahaan tersebut telah mengalami kerugian yang besar dan melakukan penjualan aset untuk pembayaran hutang perusahaan sehingga nilai aset menjadi berkurang drastis.

\section{g. Kualitas Laba memperlemah pengaruh Opportunity terhadap Fraudulent Financial Statement}

Hasil penelitian ini menolak hipotesis ketujuh. Penelitian ini menunjukkan bahwa kualitas laba tidak dapat dapat memperlemah peluang untuk melakukan tindak kecurangan laporan keuangan dikarenakan peluang atau kesempatan untuk melakukan fraud itu terjadi karena lemahnya internal control, sehingga kualitas internal control yang baik dapat meminimalisirkan risiko fraud itu terjadi. Kualitas internal control yang baik dapat dilihat dari objektivitas dan integritas dewan komisaris independen dan komite audit.

h. Kualitas Laba memperlemah pengaruh Rationalization terhadap Fraudulent Financial Statement

Hasil penelitian ini menolak hipotesis kedelapan. Penelitian ini menunjukkan bahwa kualitas laba tidak dapat memperlemah rasionalisasi terhadap kecurangan laporan keuangan dikarenakan alasan atau motivasi dewan komisaris independen dan komite audit melakukan pergantian auditor tidak selalu untuk melakukan kecurangan laporan keuangan. Contohnya motivasi positif yang digunakan untuk melakukan pergantian auditor dikarenakan ketidakpuasan pada kinerja auditor sebelumnya, sehingga tinggi rendah kualitas laba disebuah perusahaan tidak dapat dipastikan terindikasi fraud karena adanya pergantian auditor.

Copyright @ 2020 Jurnal JKI 20 (3): 269 - 280 (September 2020) 


\section{i. Kualitas Laba memperlemah pengaruh Competence terhadap Fraudulent Financial Statement}

Hasil penelitian ini menerima hipotesis kesembilan. Kualitas laba digunakan untuk mengetahui sejauh mana laba sebuah perusahaan itu dapat diperoleh berulang-ulang dan dapat dikendalikan, sehingga dapat mengetahui kemampuan yang dimiliki oleh manajemen perusahaan untuk melakukan kecurangan dalam laporan keuangan. Hal ini di dukung oleh pernyataan (Bellovary, Giacomino, \& Akers, 2005) yang mendefinisikan kualitas laba sebagai kemampuan laba dalam merefleksikan kebenaran laba perusahaan dan membantu memprediksi laba mendatang, dengan mempertimbangkan stabilitas dan persistensi laba. Laba mendatang merupakan indikator kemampuan membayar deviden masa mendatang.

\section{j. Kualitas Laba memperlemah pengaruh Arrogance terhadap Fraudulent Financial Statement}

Hasil penelitian ini menolak hipotesis kesepuluh. Penelitian ini menunjukkan bahwa tinggi rendah kualitas laba tidak dapat memperlemah pengaruh arogansi terhadap kecurangan laporan keuangan, dikarenakan superioritas yang dimiliki CEO atau jabatan tertinggi di sebuah perusahaan dapat mengintervensi jabatan dibawahnya, oleh karena itu objektivitas dan integritas dari dewan komisaris dan komite audit lebih dapat mencegah fraud yang akan dilakukan oleh CEO atau level jabatan tertinggi dalam perusahaan.

\section{Kesimpulan}

Penelitian ini bertujuan untuk menganalisis pengaruh pentagon fraud terhadap fraudulent financial statement dengan kualitas laba sebagai variabel moderasi pada perusahaan manufaktur tahun periode 2016-2017. Oleh karena itu, berdasarkan pada hasil-hasil analisis yang telah dilakukakn sebelumnya, maka dapat ditarik beberapa kesimpulan sebagai berikut:

Pressure tidak berpengaruh positif signifikan terhadap fraudulent financial statement. Hasil penelitian ini didukung oleh penelitian yang dilakukan oleh (Skousen, Smith, \& Wright, 2008) dan (Tessa \& Harto., 2016) menunjukkan bahwa pressure berpengaruh negatif dengan fraudulent financial statement.

Opportunity tidak berpengaruh positif signifikan terhadap fraudulent financial statement. Hasil penelitian ini didukung oleh penelitian yang dilakukan oleh (Skousen et al., 2008)) dan (Tessa \& Harto., 2016) yang menunjukkan bahwa opportunity tidak berpengaruh signifikan terhadap fraudulent financial statement.

Rationalization tidak berpengaruh positif signifikan terhadap fraudulent financial statement. Hasil penelitian ini didukung oleh penelitian yang dilakukan oleh (Skousen et al., 2008) dan (Tessa \& Harto., 2016) yang menunjukkan bahwa rationalization tidak berpengaruh signifikan terhadap fraudulent financial statement.

Competence berpengaruh positif signifikan terhadap fraudulent financial statement. Hasil penelitian ini didukung oleh penelitian yang dilakukan oleh (Amaliah, Januarsi, \& Ibrani, 2015) dan (Siddiq \& Zaulfikar, 20117) menunjukkan bahwa competence berpengaruh signifikan dengan fraudulent financial statement. 
Arrogance tidak berpengaruh positif signifikan terhadap fraudulent financial statement. Hasil penelitian ini didukung oleh penelitian yang dilakukan (Aprilia, 2017) yang menunjukkan bahwa arrogance tidak berpengaruh signifikan terhadap fraudulent financial statemen.

Kualitas laba tidak dapat memperlemah pressure terhadap fraudulent financial statement. Hal ini dikarenakan bisa jadi tekanan yang di lihat dari perubahan total aset mencerminkan laba yang sebenarnya bukan karena adanya manajemen laba. Contohnya perusahaan tersebut telah bangkrut sehingga nilai aset berkurang drastis.

Kualitas laba tidak dapat memperlemah opportunity terhadap fraudulent financial statement. Hal ini dikarenakan peluang atau kesempatan untuk melakukan fraud itu terjadi karena lemahnya internal control, sehingga kualitas internal control yang baik dapat meminimalisirkan risiko fraud itu terjadi dibandingkan dengan kualitas laba.

Kualitas laba tidak dapat memperlemah rationalization terhadap fraudulent financial statement. Hal ini dikarenakan tinggi rendah kualitas laba disebuah perusahaan tidak dapat dipastikan terindikasi fraud karena adanya pergantian auditor.

Kualitas laba dapat memperlemah competence terhadap fraudulent financial statement. Hal ini dikarenakan kualitas laba digunakan untuk mengetahui sejauh mana laba sebuah perusahaan itu dapat diperoleh berulang-ulang dan dapat dikendalikan, sehingga dapat mengetahui kemampuan yang dimiliki oleh manajemen perusahaan untuk melakukan kecurangan dalam laporan keuangan.

Kualitas laba tidak dapat memperlemah arrcogance terhadap fraudulent financial statement. Hal ini dikarenakan superioritas yang dimiliki CEO atau jabatan tertinggi di sebuah perusahaan dapat mengintervensi jabatan dibawahnya, oleh karena itu objektivitas dan integritas dari dewan komisaris dan komite audit lebih dapat mencegah fraud yang akan dilakukan oleh CEO atau level jabatan tertinggi dalam perusahaan.

\section{Daftar Pustaka}

Albrecht, W. S., \& Albrecht, C., \& Albrecht, C. C. (2008). Current Trends in Fraud and its Detection. Information Security Journal: A Global Perspective, 17(1).

Amaliah, B. N., Januarsi, Y., \& Ibrani, E. Y. (2015). Perspektif Fraud Diamond Theory dalam Menjelaskan Earnings Manajemen Non-GAAP pada Perusahaan Terpublikasi di Indonesia. JAAl, 19(1), 51-67.

Aprilia. (2017). Analisa Pengaruh Fraud Pentagon Terhadap Kecurangan Laporan Keuangan Menggunkan Beneish Model Pada Perusahaan yang Menerapkan Asean Corporate Governance Scorecard. Jurnal Akuntansi Riset, 6(1), 96-126.

Aprilia, O Cicilia, R. P. S. (2015). The Effectiveness Of Fraud Triangle On Detecting Fraudulent Financial Statement: Using Beneish Model And The Case Of Special Companies. Jurnal Riset Akuntansi Dan Keuangan, 3(3), 786-800.

Bellovary, J. L., Giacomino, D. E., \& Akers, M. D. (2005). Earnings Quality: It's Time to Measure and Report. The CPA Journal, 75(11), 32-37.

Siddiq, A., \& Zaulfikar. (20117). Fraud Pentagon Dalam Mendeteksi Financial Statement Fraud. Retrieved May 6, 2018, from http://publikasiislamiah.ums.ac.id/

Copyright @ 2020 Jurnal JKI 20 (3): 269 - 280 (September 2020) 
Sihombing, Samuel, K., \& Rahardjo. (2014). Analisis Fraud Diamond dalam Mendeteksi Financial Statement Fraud: Studi Empiris Pada Perusahaan Manufaktur yang Terdaftar di Bursa Efek Indonesia (BEI). Journal of Accounting Fakultas Ekonomika Dan Bisnis, Universitas Diponegoro.

Skousen, C. J., Smith, K. R., \& Wright, C. J. (2008). Detecting And Predicting Financial Statement Fraud: The Effectiveness of The Fraud Triangle and SAS No. 99.

Tessa, C. G., \& Harto., P. (2016). Fraudulent Financial Reporting: PengujianTeori Fraud Pentagon Pada Sektor Keuangan Dan Perbankan Di Indonesia. Simposium Nasional Akuntanis XIX. Lampung.

Triyanto, D. N. (2019). Fraudulence Financial Statements Analysis using Pentagon Fraud Approach. Journal of Accounting Auditing and Business, 12(2), 26-36.

Wolfe, D. T., \& Hermanson, D. R. (2004). The Fraud Diamond: Considering the Four Elements of Fraud. CPA Journal, 74(12), 38-42. 